\title{
Kentsel Sürdürülebilirlik ve Dayanıklılık Açısından Kentsel Dönüşüm Uygulamalarında Rant ve Özel Mülkiyete Bir Bakış
}

\author{
Burcu Aslan Okat ${ }^{1}$ \\ ORCID: 0000-0001-5796-5127
}

\author{
Cankut Dağdal İnce 2 \\ ORCID: 0000-0001-5954-2478
}

Öz

Sanayileşme, nüfus artı̧ı, kaynaklarm hızl tüketimi ve iklim krizi gibi sorunlarn ortaya çıkı̧̧ı ile birlikte son yillarda "sürdürülebilirlik" ve "dayanıklllk" kavramlar gündeme gelmiştir. Bunun yanı sira, tüm dünyada yaşanan COVID-19 salgın da yine insanların yoğun şekilde bir arada yaşadığı kentsel alanların sürdürülebilir, her türlü afet ve kriz karşısında dayanıkl şekilde planlanmast ve dönüştürülmesi gerektiğini gözler önüne sermiştir. Kentsel alanlarn yeniden düzenlenmesinde ve eskiyen kentsel dokunun yenilenmesinde siklkla kullanilan araçlarm başında gelen kentsel dönüşüm uygulamalarnnn, daha sürdürülebilir ve dayanikl kentsel alanlar oluşturulmasına önemli katkllar sunması beklenmektedir. Ancak Türkiye'deki kentsel dönüşüm uygulamalarnda, özel mülkiyet ve kentsel rantın, hem kamusal hem de kamusal olmayan alanlarm yeniden planlanmasının önünde baskı unsuru olabildiği görülmektedir. Bu nedenle yaplacak kentsel dönüşüm uygulamalarında ve yeni kentleşme modellerinde, özel mülkiyet haklarmın ve sinırlamalarını doğru bir şekilde belirlenmesi gerekmektedir. Bu makalede, özel mülkiyetin ve kentsel rantın, özellikle konut ve nüfus yoğunluğu açısindan kentsel dönüşümde nasil ele alnnabileceği, kısitlarmmn neler olabileceği ve yasal mevzuatlarda nasıl yer alması gerektiği tartışılmıştır.

Anahtar Kelimeler: COVID-19, kentsel dönüşüm, kentsel rant, kentsel sürdürülebilirlik ve dayanıklılık, özel mülkiyet.

\footnotetext{
${ }^{1}$ Arş. Gör., Kocaeli Üniversitesi, E-mail: burcu.aslan@kocaeli.edu.tr

2 Dr. Öğr. Üyesi, Kocaeli Üniversitesi, E-mail: cankut.ince@kocaeli.edu.tr

idealkent @ C Kent Araştırmaları Dergisi (Journal of Urban Studies)

http://idealkentdergisi.com

Geliş Tarihi Received Date: 07.01.2021 Kabul Tarihi Accepted Date: 1.09.2021
} 


\title{
An Overview of Private Property and Rent in Urban Regeneration Projects in Terms of Urban Sustainability and Resilience
}

\author{
Burcu Aslan Okat ${ }^{3}$ \\ ORCID: 0000-0001-5796-5127
}

\author{
Cankut Dağdal İnce 4 \\ ORCID: 0000-0001-5954-2478
}

\begin{abstract}
The concepts of "sustainability" and "resilience" have become current issues with the emergence of problems such as industrialization, population growth, rapid consumption of resources, and the climate crisis in recent years. In addition, the COVID-19 pandemic experience all over the world has also revealed that urban areas where people live extremely together must be planned and transformed in a sustainable and resilient manner. Urban regeneration projects are among the most frequently used tools in the reorganization of urban areas, renewal of aging urban structures. Also, urban regeneration projects are expected to make a significant contribution to designing more sustainable and resilient urban areas. However, in Turkey, it is observed that private property and urban rent issues can be a pressure factor in the re-planning of public and non-public areas in urban regeneration projects. For this reason, private property rights and limits should be determined accurately in urban regeneration projects and new urbanization models. In this paper, it is discussed how private property and urban rent can be handled in urban regeneration according to housing and population densities, what their limitations can be, and how they should be included in legal regulations.
\end{abstract}

Keywords: COVID-19, urban regeneration, urban rent, urban sustainability and resilience, private property.

\footnotetext{
${ }^{3}$ R. A., Kocaeli University, E-mail: burcu.aslan@kocaeli.edu.tr:

${ }^{4}$ Assist. Prof. Dr., Kocaeli University, E-mail: cankutince@kocaeli.edu.tr

idealkent @ Kent Araştırmaları Dergisi (Journal of Urban Studies)

http://idealkentdergisi.com

Geliş Tarihi Received Date: 07.01.2021 Kabul Tarihi Accepted Date: 1.09.2021
} 


\section{Giriş}

20. Yüzyılın ikinci yarısından itibaren kentlerin yayılması, yoğunlaşması ve kontrolsüz enerji tüketimi, özellikle kentlerde çevre sorunlarının daha fazla artmasına neden olmuştur. Bu nedenle 1972 yılında Stockholm'de düzenlenen Birleşmiş Milletler (BM) İnsan Çerçevesi Konferansı'nda ve 1992 yılında Rio Konferansı olarak bilinen BM Çevre ve Kalkınma Konferansı'nda Gündem21 kararları ile kentlerin daha sürdürülebilir şekilde planlanması gerektiğine ilişkin önemli kararlar alınmıştır (Yalçıner Ercoşkun, 2018). Genel anlamıyla kentsel sürdürülebilirlik, gelecek nesillerin haklarından çalmadan, atık üretimini en aza indirecek şekilde doğal kaynakların etkin kullanımının, ekonomik büyümenin ve refahın sağlanması şeklinde tanımlanabilir (Saunders ve Becker, 2015; Tuğaç, 2020). Birleşmiş Milletler'in 2018 yılındaki Sürdürülebilir Kalkınma Hedefleri Raporu'nun 11. Hedefi "şehirleri ve insan yerleşimlerini kapsayıcl, güvenli, dayanıklı ve sürdürülebilir kılmak" şeklinde tanımlanmıştır (Birleşmiş Milletler, 2018). Dünyadaki birçok şehirde, hızlı kentleşmenin yönetilmesi, artan nüfusların desteklenmesi, konut ve altyapı politikalarında yeterliliğin sağlanması, kentsel saçılmanın çevresel etkilerinin ve afetlere karşı savunmasızlığın azaltılması gibi ciddi zorluklarla karşılaşılmakta ve bu sorunları çözebilecek politikalar üretilmesi gerekliliği tartışılmaktadır (Kaya ve Taylan Susan, 2020).

Tarih boyunca yaşanan deprem, sel, yanardağ patlaması gibi doğal afetler ve salgınlar gibi pek çok kriz, kentlerdeki hayatı ve kent ekonomisini ağır hasarlar vererek doğrudan etkilemiştir. 20. ve 21 yüzyılda gelişen teknolojiyle birlikte kentlerin, doğal afetlere ve krizlere karşı dayanıklı şekilde planlanması da sürdürülebilirlik tartışmalarına eklenmiştir (Meerow, Newell ve Stults, 2016). Dayanıklılık kavram1, Afet Risk Azaltma Uluslararası Ofisi'nin (UNISDR) 2005 yılındaki Hyogo Eylem Planı sonuç raporunda, "Tehlikelere maruz kalmış bir sistemin, topluluğun veya toplumun, kendi temel yapıların ve işlevlerini koruma ve onarma dâhil, bir tehlikenin etkileri karşısında zamanında ve etkin bir şekilde direnme, soğurma, uyum geliştirme ve iyileşme becerisi" olarak tanımlanmaktadır (United Nations Office for Disaster Risk Reduction, 2009). Kentsel dayaniklılik ise her türlü afet ve krize hazır bir kent planlamasiyla birlikte, afetlerden sonra kentin hızla eski haline dönebilme kapasitesi olarak tanımlanabilir (Meerow ve diğerleri, 2016). Günümüzde kentsel sürdürülebilirlik ve dayanıklılığı sağlamak adına dünyada ve ülkemizde akıllı kent, kompakt 
kent, yavaş kent gibi çeşitli kent modelleri tartışılmaktadır. Akıllı kentler, bilgi ve iletişim teknolojilerini etkin bir biçimde kullanarak kentsel hizmetlerin verimliliğini sağlayan sürdürülebilirlik temelli yenilikçi bir yaklaşımdır (Aldegheishem, 2019). Akıllı kent modelleri, afet ve krizler karşısında afet bilgi sistemleri, sağlık hizmet bilgi ve iletişim sistemleri gibi çeşitli sistemler ile kentsel dayanıklılığa katkı sağlayabilirler (Öztaş Karlı ve Çelikyay, 2020).

Kentlerin mevcut çöküntü alanlarında sürdürülebilir ve dayanıklılık kriterlerinin uygulanabilmesi, yeni imara açılan alanlarına kıyasla daha zordur. Ekonomik, fiziksel veya sosyal açılardan çöküntü haline gelmiş kentsel alanların yeniden ele alınmasında imar planları ve uygulamalarının yetersiz kalabildiği tartışılmaktadır (Jones ve Evans, 2008; Roberts ve Sykes, 2000). Bu tür kentsel alanlarda; afetlere karşı dayanıksız yapılar, yetersiz kamusal alanlar, karmaşık mülkiyet yapısı ve demografik problemler gibi pek çok sorun bulunabilmektedir. Ayrıca, bu alanlarda kentsel rant beklentisi de yüksek olabildiğinden gerçekleştirilecek kentsel çözümler zorlaşabilmektedir. Kentsel rant, kentsel alanlardaki özel mülkiyet nedeniyle mülk sahiplerince kazanılan; insan emeğine dayanmayan ve doğrudan kentsel gelişim dinamikleri sonucunda oluşan bir bedeldir. Kentlerde merkezi konumda bulunan, yüksek gelir grubunun yerleşim yeri haline gelen, diğerlerinden daha fazla değere sahip olan topraklar, sahiplerine bir güç de getirmektedir (Ayman Güler, 1992; Ökmen ve Yurtsever, 2010). Bu nedenle, kentlerin yeniden düzenlenmesinde ve çeşitli kentsel problemlerin çözümünde bölge ve şehir planlar1nın yanı sıra kentsel dönüşüm uygulamaları önemli bir araç olarak kullanılmaktadır (Akkar, 2006; Donnison, 1993; Granger, 2010; Pontrandolfi ve Manganelli, 2018).

Türkiye'de, 1999 Marmara Depremi sonrasında daha fazla gündeme gelmiş olan kentsel dönüşüm uygulamaları, çoğunlukla deprem odaklı yürütülmekte; proje ve ilgili yasalarda öncelikle depreme dayanıklı toplu konut üretimi hedeflenmektedir (Akyıldız ve Girgin, 2017; Tümler ve Karagüler, 2020). Son yıllarda, afet riski altındaki bölgelerde veya riskli yapılarda 6306 Sayılı Afet Riski Altındaki Alanların Dönüştürülmesi Hakkında Kanun kapsamında gerçekleştirilen kentsel dönüşüm uygulamaları hız kazanmıştır (Çelikbilek ve Öztürk, 2017; Demirkol ve Bereket Baş, 2013; Güzey, 2016; Türkiye Büyük Millet Meclisi, 2012). Ancak bugün gelinen noktada, kentlerin sadece deprem değil salgınlar gibi pek çok konuda risk altında olduğu ve deprem odaklı yenilemenin ye- 
terli olmayacağı ortadadır. Tarih boyunca salgınlar da doğal afetler ve savaşlar kadar kentleşme tarihini etkilemiştir. 20. yüzyılda İspanyol gribi, Asya gribi, AIDS, Ebola gibi birçok salgın yaşanmıştır. 21.yüzyılın ilk 20 yılında dahi, domuz gribi, kuş gribi, SARS, MERS, Zika gibi birçok yeni salgınla karşılaşılmış olup; günümüzde COVID-19 pandemisinin etkileri Türkiye'de ve tüm dünyada halen yoğun şekilde hissedilmektedir. Bu süreçte alınması gereken önlemler ile kentleşme, altyapı ve ulaşım modelleri üzerine çeşitli çalışmalar ve tartışmalar sürmektedir (Batty, 2020; Carozzi, Provenzano ve Roth, 2020; Gargiulo ve diğerleri, 2020; Honey-Rosés ve diğerleri, 2020; Öztaş Karlı ve Çelikyay, 2020; Salama, 2020; Yaman-Galantini, 2021). Kentsel yoğunluğun fazla olduğu ve temel hizmetlere erişimin az olduğu yerlerde hastalığın hızlıca yayıldığı, dünya kentleri ve ülkemizdeki vakaların dağılımı incelendiğinde görülebilmektedir (Carozzi ve diğerleri, 2020; Desai, 2020; Hamidi, Sabouri ve Ewing, 2020; Kasapoğlu, 2020; Kocaeli Ses Gazetesi, 2020). Kentsel yoğunluğun, vaka ve ölüm sayıları ile doğrudan ilişkisinin bulunmadığını belirten çalışmalar olsa da (Boterman, 2020) nüfus yoğunluğunun bir sonucu olarak kamusal alanların yetersizliğinden kaynaklı sorunların merkezinde yine kentleşme politikalarının bulunduğunu söylemek yanlış olmaz. Bu doğrultuda, kentsel alanların ortaya çıkan yeni hastalıklar ve afetler karşısında hazırlıklı olabilecek şekilde yeniden düzenlenmesi gerektiği açıtır. Kamusal alanların başta ulaşım, altyapı, eğitim ve sağlık hizmetlerini çok daha etkin kılacak şekilde yeniden düzenlenmesi ve kentsel yoğunluğun azaltılması, bunun yanında kentsel saçılmanın da önüne geçilmesi; bir nevi bunlar arasında bir denge oluşturulması gerekmektedir. 2020 Dünya Şehirleri Raporu'nda da COVID19 salgınının kentlerde ekonomik açıdan belirsiz bir yatırım ortamı yarattığ belirtilerek kentlerdeki yoğun insan etkileşiminin, ekonomik büyümeyi hızlandırdığından ancak bu yoğunluğun, COVID-19 pandemisinde görüldüğü gibi bazı riskler barındırdığından bahsedilmiştir. Bu nedenle kentlerdeki yoğunluktan faydalanılması fakat kalabalıklaşmanın da önüne geçilmesi gerektiği vurgulanmıştır (United Nations Human Settlements Programme, 2020). Bu noktada optimal (en uygun) kent büyüklüğü ve yoğunluğu kavramları karşımıza çıkmaktadır. Literatür incelendiğinde optimal kent büyüklüğü ya da yoğunluğunun belirlenmesi konusunda farklı tanımlamalar ve çalışmalar (Arnott, 1979; Cusack, 2017; Yang, 2020; Yarmohammadian, Asgary, Akbari ve Movahedinia, 2014) olmasına rağmen bu ölçütlerin ne olacağı konusu hala net şekilde tanım- 
lanmış değildir. Bir çalışmada, sera gazı emisyonları, yerel hava kirliliği ve trafik sıkışıklığı gibi sürdürülebilirlik hedefleri açısından verimli bir kentsel yoğunluğun hektar başına 50 ila 150 kişi arasında kalması gerektiği vurgulanmıştır (Lohrey ve Creutzig, 2016).

Dünyada sürdürülebilir ve dayanıklı kentler oluşturulabilmesi adına çeşitli kentsel modeller tartışılmakta ve uygulamalarına geçilmektedir (Aldegheishem, 2019; Chen, Xu, Zhao, Xu ve Lei, 2020; Mattoni, Pompei, Losilla ve Bisegna, 2020; Nesticò ve Sica, 2017). Ülkemizde de bu modeller konu edilmekle birlikte uygulamaları oldukça sınırlı ve az sayıdadır (Karasu Asnaz, 2019; Öztaş Karlı ve Çelikyay, 2020; Yaman Galantini, 2018). Kentsel dönüşüm uygulamaları, günümüzde kentleşme ile ilgili alınan her türlü kararda en önemli araçların başında geldiğine göre, bu uygulamaların kentsel sürdürülebilirliğe ve dayanıklılığa katkı vermesi beklenmelidir. Ancak Türkiye'deki kentsel dönüşüm uygulamaları, insanların mülkiyet haklarının sınırlandırılması, yaşam alanlarından uzaklaştırılması, yüksek katlı binalarda yaşamaya zorlanması ve oluşan rantın adaletsiz şekilde paylaşımı gibi pek çok konuda tartışmalara yol açmiştır (Ince ve Aslan, 2019; Özcan, 2000; Turan, 2008).

Bu makale, özellikle çöküntü alanı haline gelen bölgelerde uygulanan kentsel dönüşüm projelerindeki özel mülkiyetin ve kentsel rantın, bu dönüşüme ve dolaylı olarak da kentsel sürdürülebilirlik ve dayanıklılığa olumsuz etkilerini tartışmaya açmak için yazılmıştır. Tartışmada örnek olarak, Kocaeli'deki ikisi tamamlanmış, biri planlama aşamasında olmak üzere üç kentsel dönüşüm projesine ait bilgiler kullanılmıştır. Bu uygulamalara ait parsel, malik ve hisse bilgileri birbirileri ile ilişkilendirilerek Coğrafi Bilgi Sistemi (CBS) üzerinde birer veri tabanı oluşturulmuştur (Arıcan, Dündar ve Güven, 2018; Aslan, 2017; Başkaya, 2019; Ince ve Aslan, 2019). CBS üzerinden mülkiyet ve yoğunluk için yapılan analiz ve bulgular 1şığında özel mülkiyetin ve kentsel rantın, kentsel dönüşümde nasıl ele alınabileceği, kısıtlarının neler olabileceği ve yasal mevzuatlarda nasıl yer alabileceği tartışılmıştır.

\section{Kentsel Sürdürülebilirlik ve Kentsel Dayanıklılık}

Günümüzde sanayileşme ve teknolojik gelişmeler, hammaddeleri hızla tüketmekte; çevresel ve ekonomik sorunlar ortaya çıkarmaktadır. Sanayileşmenin bir sonucu olarak kentlerde yaşayan nüfusun artması, altyapı, ulaşım ve atık yönetimi açısından talepleri çoğaltmakta; planlama dina- 
mikleri ve çevre üzerinde baskı oluşturmaktadır. Plansız yapılaşmanın yanı sıra kentsel yayılma, doğal alanların tahribine ve çevresel yaşam kalitesinin bozulmasına sebep olmaktadır (Ulubaş Hamurcu ve Aysan Buldurur, 2017). Tüm bunlar göz önüne alındığında kentlerin sürdürülebilir şekilde planlanması ve kentsel dönüşüm faaliyetlerinin sürdürülebilirlik ölçütlerine göre düzenlenmesi günümüzde giderek önem kazanmıştır (Saunders ve Becker, 2015; Zheng, Shen ve Wang, 2014).

Kentsel planlamanın sürdürülebilirliği, kentleşmenin çevresel ekonomik ve sosyal ilkelerle uyumlu hale getirilmesi ile ilgilidir. Günümüzde, bu uyumlaştırma sürecinde, düşük enerji tüketimi, yenilenebilir enerji kaynaklarının verimli kullanımı, ekolojik ilkelere uygun olarak kentsel arazi kullanımı ve halkın karar alma süreçlerine katılımı ön plana çımaktadır. Kentsel sürdürülebilirlik için çeşitli göstergeler belirlenmiştir (Peng, Lai, Li ve Zhang, 2015; Ulubaş Hamurcu ve Aysan Buldurur, 2017; Yıldız, Kıvrak ve Gültekin, 2015; Zheng ve diğerleri, 2014). Ancak, bu göstergeler, her şehrin ihtiyaç, hedef ve kapasitesine göre belirlenmeli; kentler, kendi sürdürülebilirlik modellerini oluşturmalı; yerel yönetimler bu modelleri analiz ederek denetleyebilmelidir. Dünyada pek çok şehirde sürdürülebilirlik hedeflerinin ne kadar gerçekleştiğini analiz eden çeşitli çalışmalar vardır (Mattoni ve diğerleri, 2020; Peng ve diğerleri, 2015; Shen, Ochoa, Shah ve Zhang, 2011). Ülkemizde ise bu süreçlerin henüz çok başında olunduğu söylenebilir. Her ne kadar akademik çalışmalarda sürdürülebilirlik kavramından bahsedilse de bu hedef ve ölçütlerin yasalarımızda ya da uygulamalarda yeterince yer bulabildiğini söylemek oldukça zordur (Çahantimur ve Turgut Yıldız, 2008; H. Haştemoğlu ve Özgen, 2017; Korkmaz ve Balaban, 2020).

Kentler, doğal ya da doğal olmayan pek çok afetin yıkıcı etkilerine karşı hazırlıksız ve kırılgan olabilirler. Doğal afetlerin çoğunun hala tahmin edilemez olmasının da bu durum üzerinde etkisi büyüktür. Yaşanan COVID-19 salgını, insanlığın medeniyeti inşa ettiği kentlerin çok daha etkili ve çok boyutlu bir krizle karşı karşıya kalabileceğini de göstermektedir. Kentleşme politikalarının, bu salgına hazırlıksız yakalanılmasında ve hastalığın hızlıca yayılmasında son derece etkili olduğu görülmüştür. Özellikle yoğun yapılaşmanın olduğu kentlerde salgının yayılımının arttığı tartışılmaktadır (Carozzi ve diğerleri, 2020; Cotella ve Brovarone, 2020; Honey-Rosés ve diğerleri, 2020). Kentlerde yeşil alanlar gibi kamuya açık alanların azalmasının ve kentlerin nüfusun yoğunlaştığ1 kapalı alanlar haline gelmesinin yine salgının etkilerinin daha fazla 
hissedilmesine sebep olduğu görülmüştür (Öztaş Karlı ve Çelikyay, 2020; Sayın ve Bozkurt, 2020). Bazı başarısızlıklar sağlık sistemlerine, altyapıya, idari yapıya, ekonomik zayıflıklara vb. faktörlere bağlansa bile kent planları ve genel anlamıla planlama mantığı tüm bu faktörlerin düşünülerek tasarlanması ve geliştirilmesi gereken organik bir sistemdir. $\mathrm{O}$ halde, küresel olarak yaşanan bu salgın; kentlerin benzer salgınlara karşı yeterince dayanıklı olmadığını gözler önüne sermiştir (TMMOB Şehir Plancıları Odası, 2020).

Kentsel dayanıklılık kavramından beklenen temel nitelikler; beklenmedik tehditlere cevap verebilme, bu tehditler karşısında uyum sağlama, başa çıkabilme ve yeniden organize olabilme kapasitelerini geliştirme şeklinde kısaca sıralanabilir. Kent planlama araçlarının dayanıklılığın niteliklerini sağlayacak şekilde ele alınması günümüzün önemli tartışmalarından birini oluşturmaktadır (Yaman Galantini, 2019). Günümüzde COVID-19 salgınının kentlerin dayanıklılığını test ettiği bir süreç yaşanmaktadır. Salgında kentlerde yaşanan kırılganlıklar, uyum sağlama konusundaki eksiklikler ve yeniden organize olamama nedenleri kentlere özgü şekilde ekolojik, ekonomik ve sosyal açılardan farklılıklar gösterebilmektedir. Bu nedenle, kent planlama araçlarının dayanıklılığın bu temel niteliklerine katkı sağlayacak şekilde ele alınması gerekmektedir. Ülkemizde kentsel dönüşüm uygulamaları da bir kent planlama aracı olarak aktif bir şekilde kullanıldığına göre, dönüşümlerin bu nitelikler üzerinden kentsel dayanıklılığa katkı sunması beklenir. Şimdiye kadar ülkemizde gerçekleştirilen kentsel dönüşüm uygulamaları, başta deprem olmak üzere heyelan, sel gibi afetlere karşı daha dayanıklı kentler oluşturma çabası olarak görülebilir. Ancak; kentsel dönüşüm kavramı, salgınlara da hazırlıklı sürdürülebilir ve dayanıklı kentsel alanlar oluşturmak adına yeniden ele alınmalıdır.

\section{Kentsel Dönüşüm Uygulamalarında Mülkiyet ve Kentsel Rantın Kentsel Sürdürülebilirlik ve Dayanıklılık Açısından İrdelenmesi}

Kentlerin, değişimlere karşı adapte olabilir kapasitede tasarlanan kent planlarına göre gelişmesi ve yönlendirilmesi sağlıklı kentleşme için en önemli unsurdur. Ancak, ülkemizde 1950'lerden sonra hızla büyüyen kentler için planlama yapmak mümkün olamamış; planlama yapılsa dahi uygulanamamış ya da yetersiz kalmıştır. Kentler kendi iç dinamikleriyle ve o anki ihtiyaçlara kendi çözümlerini bularak gelişmişlerdir. 
Daha sonraları kamu iradesi, kendiliğinden oluşan bu kentleşme modellerine uyum sağlayan imar planı düzenlemeleri ve çeşitli aflar ile çözümler getirmeye çalışmıştır. Geleceğe dönük olmayan bu plansız kentleşme yapısı, günümüze gelindiğinde çağın gerekliliklerine uyum sağlamanın çok uzağında kalmıştır. Kentsel dönüşüm faaliyetleri ve bu alandaki yasal düzenlemeler, eski imar planlarının ve çarpık kentleşmenin tümden düzenlenebilmesine çözüm fırsatı sunmaktadır. Ancak kentsel politikalar ve uygulamalar; sağlıklı kentleşmeyi, toplum yararını, temel hak ve özgürlükleri hedeflemesi gerekirken; toplum nezdinde yerleşmiş özel mülkiyet anlayışı, rant beklentisi gibi iç içe geçmiş pek çok kısıtlama ve engelle karşılaşmaktadır. Mülkiyet ve rant gibi konuların bu girift ve birbirlerini etkileyen yapısı nedeniyle, şehirlerin daha sağlıklı, planlı ve sürdürülebilir olması için gerekli eylem adımları ağırlaşmakta ve zorlaşmaktadır (Şekil 1).

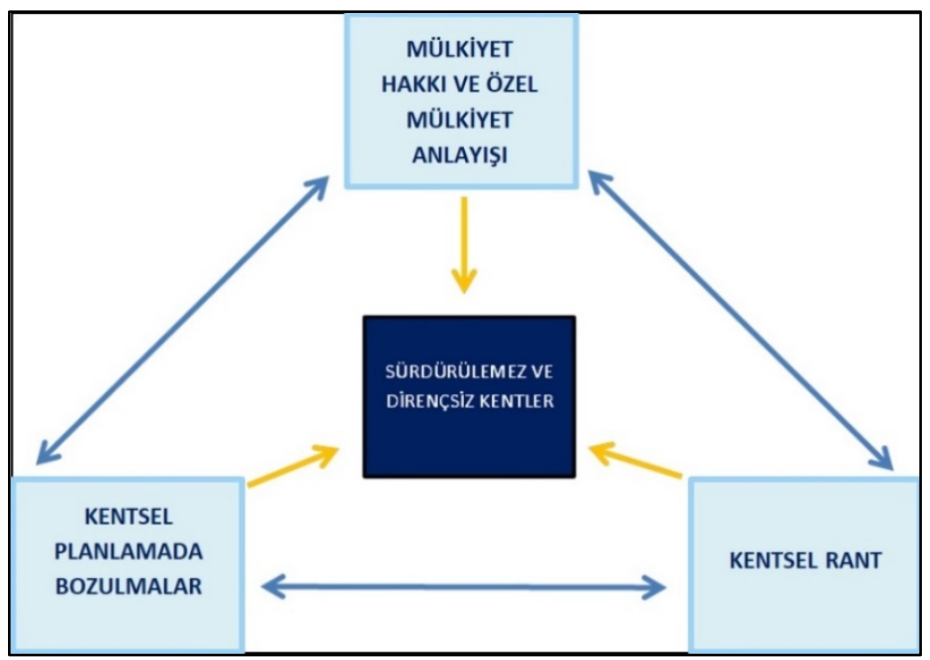

Şekil 1. Mülkiyet, rant ve kentsel planlama ilişkisi

Kentsel dönüşüm faaliyetleri ile birlikte, mülkiyet ve rantın sürekliliği ya da kısıtlanması üzerindeki yasal durumlarının araştırılması ve değerlendirilmesi gerekliliği açıktır. Ayrıca bu durumların kentsel alanlar üzerinde yarattığı ve yaratabileceği etkilerin kentsel sürdürülebilirlik ve dayanıklılık kavramları üzerinden değerlendirilmesi, gerçekleştirilecek kentsel dönüşüm uygulamalarına referans olabilmesi açısından önemlidir. 


\section{Özel mülkiyetin kentsel dönüşüme etkilerinin irdelenmesi}

Türkiye'de mülkiyet kavramı, özel mülkiyet anlayışına uygun olarak düzenlenmiş olup; mülkiyet hakkı, Anayasa'nın 35. Maddesine göre malikin malını ve toprağını ancak toplum yararı ile ters düşmüyorsa dilediği gibi kullanabileceği şeklinde tanımlanmıştır (Anayasa Mahkemesi, 2019).

Özel mülkiyetin kentle ilgili alınacak her türlü kararda en önemli rolü oynaması, kentsel planlama çalışmalarını doğrudan etkilemektedir. Özellikle günümüzde taşınmaz mülkiyetinin hala miras bırakılacak bir yatırım aracı olarak görülmesi ve ekonomik bir güvence olarak algılanması, planlama faaliyetleri ve kentsel tasarım üzerinde çeşitli baskılar yaratan durumların başında gelmektedir. Kentsel alanlardaki özel mülkiyetin, ailenin altsoylarına miras bırakılan bir yatırım aracından çıkarılarak kentlerimizin sürdürülebilirlik ilkeleri gelecek kuşaklara bırakılan bir dünya mirası haline getirilmesi gerekmektedir. Özel mülkiyetin maksimum faydacı yapısı, kentsel dönüşümün temel ilkeleriyle çeliştiği gibi kentlere zarar da verebilmektedir.

Ülkemizde 6306 Sayılı Kanun (Türkiye Büyük Millet Meclisi, 2012) ve Belediye Kanunu 73. Maddesi (Türkiye Büyük Millet Meclisi, 2010) ile gerçekleştirilen kentsel dönüşüm projeleri ile ilgili yapılan çalışmalarda, uygulama alanlarının iyileştirilmesi, yenilenmesi, afet riskli alanların dönüştürülmesi gibi amaçların ön planda tutulduğu ancak yerel halkın barınma, konut ve mülkiyet hakları gibi konuların göz ardı edilebildiği ifade edilmektedir (Demirkol ve Bereket Baş, 2013; Mutlu Laboç, 2020; Ökmen ve Bayar, 2016; Şahin, 2015; Tuğcu ve Vural Arslan, 2018). Kocaeli'de gerçekleştirilen çeşitli kentsel dönüşüm uygulamaları incelendiğinde mülkiyet değişimi açısından farklı uygulamalar görülmektedir. Örneğin 2011 yılında alınan karar ile 5393 Sayılı Belediye Kanunu'nun 73. Maddesine göre gerçekleştirilen, (Bakanlar Kurulu, 2011) Kocaeli'nin ilk kentsel dönüşüm uygulamasının 1. Etabı olan İzmit Erenler Cedit Kentsel Dönüşüm Projesinde, mülkiyet haklarını korumaya öncelik verildiği yorumu yapılabilir (Ince ve Aslan, 2019). Bu uygulamada, bölge o dönemde çok az yapılaşmış bir alan olup mülkiyetler genellikle arsa sahipliği şeklindedir. Proje, en küçük hisse sahibi vatandaşlara dahi borçlanarak da olsa yeni projeden konut/konutlar alma hakkı tanımıştır. Proje, 1999 Kocaeli Depremi sonrasında; bölge halkının depreme dayanıklı konut sorununu gidermek, yeni konut alanları açmak ve şehrin kuzeye 
yöneltilmesi gibi amaçlarla gerçekleştirilmiş; yerel mülk sahiplerinin bölgeden birden fazla konut alabilmesine hak tanımıştır.

Kocaeli'deki bir diğer kentsel dönüşüm uygulaması olan Gölcük Deniz Evler Kentsel Dönüşüm projesi mülkiyet değişimi açısından incelendiğinde ise, ortaya daha farklı bir tablo çkmaktadır. Bu proje, 1 Haziran 2015 tarihli Bakanlar Kurulu kararı ile 6306 sayılı Afet Riski Altındaki Alanların Dönüştürülmesi Hakkında Kanunun 2. maddesine göre gerçekleştirilmiştir (Bakanlar Kurulu, 2015a). Bu karara göre, Deniz Evler Mahallesi riskli alan ilan edilerek imar durumu, konut alanından sanayi alanına dönüştürülmüştür. Deniz Evler Mahallesinde konut sahibi olanlara, Sivritepe rezerv alanından yeni konut alma hakkı sunulmuş; yalnızca arsa sahibi olanlara ise konut hakkı tanınmamıştır. Bu projede yerel halkın özel mülkiyetten doğan haklarının devamlılığı, mevcut konut hakları üzerinden tanımlanmıştır. Erenler Cedit uygulamasında küçük arsa hissesi sahiplerine dahi konut/konutlar alma hakkı tanınırken bu projede sadece konut sahibi olan maliklere, sahip oldukları konut sayısı kadar yeni projeden konut alma hakkı sunulmuştur. Bölgede konut sahibi olan malik sayısı 268 ve sahip oldukları eski konut sayısı 497 iken; uygulama sonrası proje alanından konut almayı tercih eden malik sayısı 100, bu maliklerin aldıkları konut sayısı ise 142 olmuştur. Ancak, rezerv alanında toplam 541 konut inşa edilmiştir. Özetle; kentsel dönüşümde proje şartlarına göre yerel hak sahiplerine yeni proje alanından verilecek konut sayısı 142 iken fazladan 399 konut inşa edilerek, bölgeye dışardan gelecek yeni malikler yaratılmıştır (Tablo 1).

Tablo 1. Deniz Evler Kentsel Dönüşüm Projesinde maliklerin Sivritepe Rezerv Alanından konut alma tercihlerinin dağılımı

\begin{tabular}{ll}
\hline Kentsel dönüşüm öncesi malik sayısı (Deniz Evler) & 558 \\
\hline Kentsel dönüşüm ile konut alma hakkı olan malik sayısı & 268 \\
\hline Kentsel dönüşüm öncesi eski konut sayısı & 497 \\
\hline Konut alma hakkı olup konut alan malik sayısı & 100 \\
\hline Kentsel dönüşüm projesindeki toplam yeni konut sayısı (Sivritepe) & 541 \\
\hline Konut alan maliklerin toplam yeni konut sayısı & 142 \\
\hline
\end{tabular}

$\mathrm{Bu}$ projeler incelendiğinde mülkiyet üzerine tartışılması ve analiz edilmesi gereken pek çok konu olduğu ortaya çıkmaktadır. Bunlardan ilki, konut sahiplerinin barınma hakkının korunup korunmadığı konusudur. Eski konut sahiplerinin bir kısmının maddi nedenlerle yeni projeden borçlanarak konut alamamaları ve belki de evsiz kalmaları önemli 
bir sosyal sorundur. Diğer yandan, kentsel dönüşüm projelerinde fazladan konut üretilerek, satış yoluyla bölgeye yeni maliklerin yerleşmesinin dolayısıyla da bölgede yoğunluğun artmasının önü açılmaktadır. Mülkiyet açısından tartışılması gereken bir diğer konu ise, kentsel dönüşüm sonrasında maliklere tanınan konut haklarının durumudur. 6306 Sayılı Kanunun Uygulama Yönetmeliğinin 13. Maddesi 2. Fikrasında riskli alan ilan edilerek gerçekleştirilen projelerde, birden fazla konut veya işyeri alınabileceği vurgusu yapılmıştır (Çevre ve Şehircilik Bakanlığı, 2012). Bu durum, mülk sahiplerinin kentsel dönüşüm uygulamasından maksimum sayıda konut elde etme arzusuna bir sinırlandırma getirmemektedir. Kentsel dönüşüm uygulamalarında özel mülk sahiplerinin konut haklarının üst sınırları, kentlerdeki yoğunluk artışını önlemek adına mutlaka modellenmeli ve tanımlanmalıdır. Özel mülkiyet hakkının kutsallığı ve korunmasının yanında fazla konut hakkının kentsel dönüşüm uygulamalarının planlaması sürecinde bir baskı unsuru oluşturup oluşturmadığı tartışılmalıdır. Bu nedenle yapılacak kentsel dönüşüm uygulamalarında, özel mülkiyet haklarının ve sınırlarının doğru bir şekilde tanımlanması kentsel sürdürülebilirliğin ve dayanıklılı̆̆ın önemli ödevlerinden biri olacaktır.

\section{Kentsel rantın kentsel dönüşüme etkilerinin irdelenmesi}

Korkut Boratav rant kavramını, toprak ile ilişkili olarak ele almıştır. Boratav'a (2004) göre, verimsiz toprak dişında kalan tüm topraklar devamlı olarak rant yaratır ve talep arttıkça fiyatlar yükselerek rantı da büyütür (Boratav, 2004). Kentleşme aşamasında tarım arazileri arsa haline dönüştürülürken, tarımsal kullanım değeri üzerinden satın alınmakta ve imar sonucunda oluşan fazla değer üzerinden satılmaktadırlar. Buna ek olarak, kentlerde merkezi konumda bulunan ve diğerlerinden daha fazla değere sahip olan arsalar, yüksek gelir grubunun yerleşim yeri haline gelerek sahiplerine fazladan bir güç de kazandırmaktadır. Ancak, planlı kentleşmenin ana amaçlarından birisi, en önemli doğal kaynakların başında gelen toprağın korunmasıdır. Ne yazık ki, imar planları çoğu zaman bu durum üzerinden spekülasyona konu olmaktadır (Çelik, 2007; Ökmen ve Yurtsever, 2010).

Tarım arazilerinin imara açılması sürecinde kentsel bir rantın oluşması kaçınılmazdır. Ancak önemli olan, imarla elde edilen rantın, daha fazla kamu yararına dönük hale getirilebilmesidir (Sevindik, 2009). Ülkemizde, kentsel alanların günden güne kıymetlenmesi nedeniyle, daha az 
arsa kullanılarak daha fazla konut yapma amacı güdülmeye başlanmış; konut ihtiyacını karşılamak amacıyla ne yazık ki imar planlarındaki kat sayılarının arttırılması yoluna gidilmiştir. Böylesi bir yapılaşma şeklini kadastral açıdan ve imar açısından desteklemek, aynı zamanda mülkiyet haklarını da yasal bir zemine ulaştırmak amacıyla 1965 yılında çıkarılan Kat Mülkiyeti Kanunu (Türkiye Büyük Millet Meclisi, 1965), kat ve daire mülkiyetine yasal çerçeve sağlamakla birlikte yapsatçılığı da hızlandırmıştır (Önal, 2010; Turan, 2008). Yapsatçılık; genellikle kat karşılığı olarak elde edilen arsalar üzerinde yapilan konutların en az maliyet ve en yüksek kâr ile satılmasını hedeflediğinden, üretilen binaların altyapısında ve toplumsal hizmet donanımlarında önemli eksiklikler bulunabilmektedir. Ayrıca yapsatçıların ve arsa sahiplerinin, imar haklarının arttırılması için yerel yönetimler üzerinde baskı oluşturarak yapı ve yerleşme yoğunluklarının artmasında pay sahibi oldukları da tartışılan konuların başında gelmektedir. Yapsatçılığın ve rantın kentler üzerindeki doğrudan etkisi; siyaset ve belediyeler, belediyeler dolayısıyla da imar planları ve plan notları üzerinden okunabilir (H. Ş. Haştemoğlu, 2006; Özcan, 2000; Selçuk, 2013; Sevindik, 2009; Tekeli, 1988). Yapılan bir araştırma; 3194 Sayılı İmar Kanunu'nun yürürlüğe girdiği 1985 yılından 1997 yılına kadar yerel yönetimler tarafından gerçekleştirilen plan değişiklerinin nedenleri ve sonuçları hakkında çeşitli bilgiler vermektedir. Bu çalışma, plan değişikliklerinin çoğunun, farklı imar fonksiyonuna sahip alanların konut alanlarına dönüştürülmesi ve yeni konut alanları açılması üzerine olduğunu göstermiştir. Kamu alanından çıkartma, yapı düzeninde değişim, kat artışı, yol güzergahının değiştirilmesi ve yine kat artışına sebep olan yol genişlemelerine ilişkin değişiklik talepleri de eklendiğinde, plan değişikliklerinin çok büyük bir bölümü, kentlerde yoğunluğun artmasına sebep olmakta ve kentsel rant dağılımını önemli ölçüde etkilemektedir (Ersoy, 1997). Buradan hareketle, rant arzusunun kentsel planlamay1 zorlaştırdığı ve baskıladığı, kamusal alanları daralttığı ve kentleri yoğunlaştırdığı söylenebilir.

Tablo-1'de gösterilen Deniz Evler Kentsel Dönüşüm Uygulamasında maliklerin Sivritepe Rezerv Alanından konut alma tercihlerinin dağılımı yeniden incelendiğinde, Sivritepe'de yapılan 541 konuttan yalnızca 142 'sinin bölge sakinlerine verildiği görülmektedir. Fazladan üretilen konutlar ise farklı fiyatlardan satışa sunulmuştur. Eski maliklere $\mathrm{m}^{2}{ }^{\prime} \mathrm{si}$ yaklaşık 1150 TL'den verilen konutlar, yeni alıcılara m² $^{2}$ si yaklaşık 2200 
TL'den satılmaktadır. Buradan görüleceği üzere, devlet ve TOKİ'nin bu uygulamadan ne derece bir kar elde ettiği kolayca hesaplanabilir.

Yine Kocaeli'nin İzmit ilçesine bağlı Cedit Mahallesinde 2015 yılında alınan Bakanlar Kurulu kararı ile 6306 Sayılı Kanun'un 2. Maddesine göre riskli alan ilan edilerek uygulanacak olan kentsel dönüşüm projesinin rant konusundaki bilgileri de dikkat çekicidir (Bakanlar Kurulu, 2015b). Eski imar planına göre, 3 kata kadar izin verilen mahallede, kentsel dönüşüm sonrasında yüksek katlı binalar yapılması tasarlanmış ancak yaşanan tartışmalar nedeniyle bu planın uygulanmasından vazgeçilmiştir (İhlas Haber Ajansı, 2020; İşte Kocaeli Gazetesi, 2020). Planı iptal edilen projenin tanıtım broşüründe mülk sahiplerine elde edebilecekleri getiri üzerinden yapılan bazı hesaplamalar, oluşabilecek rantın boyutlarını göstermektedir (Şekil 2). Bu broşürde, hak sahiplerine oluşacak ranttan pay verilerek dönüşümün cazip hale getirilmeye çalışıldığı görülmektedir. Böylece kentsel dönüşüm ile yüksek katlı binalar ve yoğun kentleşmenin önü açılmakta; rantın, hak sahipleri ve müteahhit arasında "bir şekilde" bölüşümü ile kentin ve kentlilerin geneli konu dışında bırakılmaktadır.

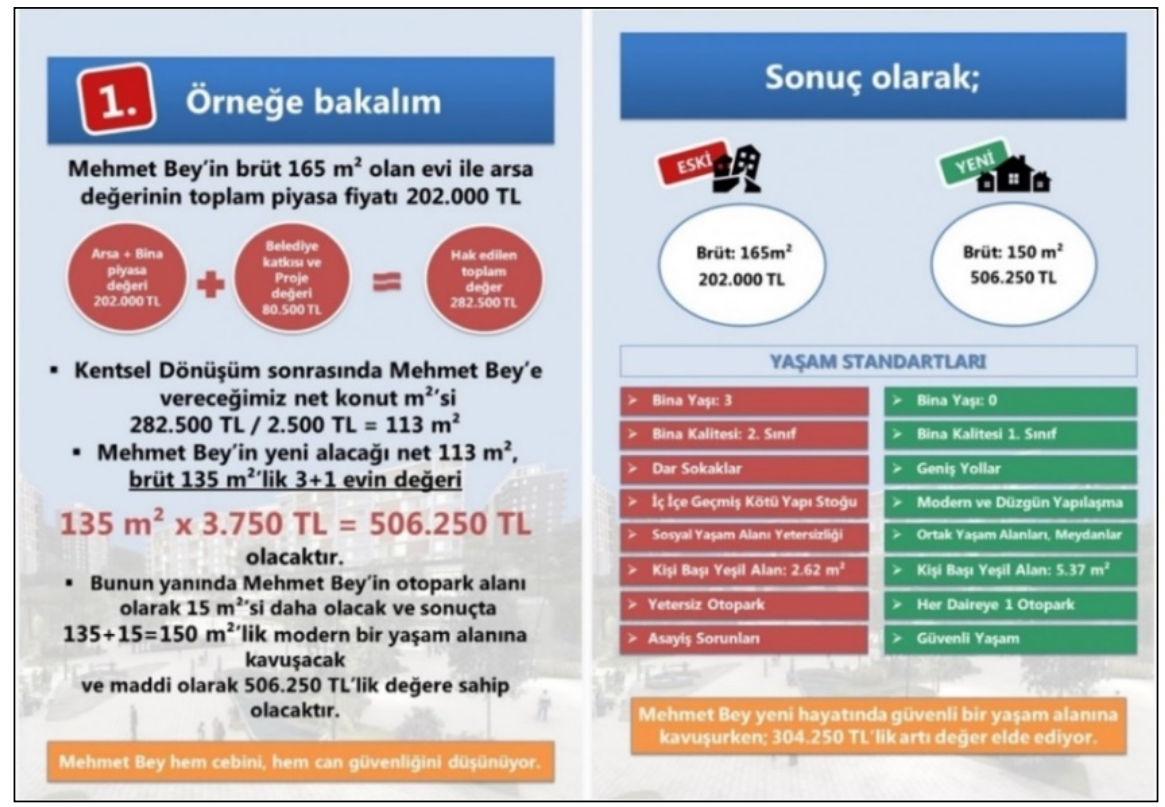

Şekil 2. Cedit Mahallesi Kentsel Dönüşüm Projesi kitapçığı (www.izmit.bel.tr) 
Kocaeli Büyükşehir Belediyesi'nden elde edilen 2018 verilerine göre Kocaeli'nin İzmit ve Gölcük ilçelerinde hane başına düşen nüfus sayısı ortalama 3,19'dur (Kocaeli Büyükşehir Belediyesi, 2019). Kentsel dönüşüm uygulamaları için oluşturulan CBS'deki veri tabanları üzerinden yapılan analizler sonucunda yoğunluk artışı ile ilgili bazı bulgulara ulaşılmış; bu bulgular Tablo 2'de özetlenmiştir. Tablo 2 incelendiğinde tamamlanmış olan her iki kentsel dönüşüm uygulamasında da maksimum eski nüfus yoğunluklarının yaklaşık \%25 arttırılarak hektar başına 170 'lerden 200'ün üzerine çıkarıldığı görülmektedir. 2019 yılında Türkiye kentlerinin il merkezlerinin kentsel yoğunlukları üzerine yapılan bir çalışmada (Sılaydın Aydın ve Kahraman, 2019) Kocaeli ilinin kentsel yoğunluğunun hektar başına 113,8 kişi olduğu tespit edilmiştir. Ancak yapılan kentsel dönüşüm uygulamalarının bunun neredeyse iki katına çıkaracak şekilde bir yoğunluk artışına sebep olduğu bulgusuna da ulaşılmaktadır. Bu yoğunluk artışlarının önemli sebeplerinden biri, daha fazla rant için üretilen fazla konut sayılarıdır.

Tablo 2. Kocaeli'den çeşitli kentsel dönüşüm uygulamalarının kentsel yoğunluğa etkisi

\begin{tabular}{llll}
\hline & $\begin{array}{l}\text { 1. Kentsel } \\
\text { Dönüşüm } \\
\text { Projesi } \\
\text { (İzmit) }\end{array}$ & $\begin{array}{l}\text { Deniz Evler ve } \\
\text { Sivritepe Kentsel } \\
\text { Dönüşüm Projesi } \\
\text { (Gölcük) }\end{array}$ & $\begin{array}{l}\text { Cedit Mahallesi } \\
\text { Kentsel Dönüşüm } \\
\text { Projesi (Planlanan) } \\
\text { (İzmit) }\end{array}$ \\
\hline $\begin{array}{l}\text { Eski imar planına göre } \\
\text { tahmini maksimum } \\
\text { konut rezervi }\end{array}$ & 4100 & 1100 & 484 \\
\hline $\begin{array}{l}\text { Yeni imar planına } \\
\text { göre tahmini konut } \\
\text { rezervi }\end{array}$ & 4906 & 541 & - \\
\hline $\begin{array}{l}\text { Eski imar planına göre } \\
\text { tahmini maksimum } \\
\text { nüfus }\end{array}$ & 13079 & 3509 & 1549 \\
\hline $\begin{array}{l}\text { Yeni imar planına } \\
\text { göre tahmini nüfus }\end{array}$ & 15650 & 1726 & - \\
\hline Eski alan (ha) & 76.89 & 19.90 & 12.62 \\
\hline Yeni alan (ha) & 76.89 & 7.45 & - \\
\hline $\begin{array}{l}\text { Eski maksimum } \\
\text { yoğunluk (nüfus/ha) }\end{array}$ & 170.1 & 176.3 & 12274 \\
\hline $\begin{array}{l}\text { Yeni yoğunluk } \\
\text { (nüfus/ha) }\end{array}$ & 203.5 & 231.6 & - \\
\hline Yoğunluk artı̧ı (\%) & 19.7 & 31.4 & - \\
\hline
\end{tabular}


Tüm bu örneklerde görüldüğü gibi, 6306 Sayılı Kanun ile riskli alan ilan edilerek gerçekleştirilen projelerde, müteahhitlerin satış amaçlı olarak fazladan ne kadar konut üretebileceklerine dair herhangi bir sınır konmamıştır. Kentsel alanlarda yoğunluğun daha fazla arttırılmaması gerekliliği göz önünde bulundurulduğunda bu tip bir kisttlamanın bulunmamas1, rant arzusunu daha da tetikleyebilmektedir. Ayrica, 6306 Sayılı Kanun ve Belediye Kanunu 73. Maddesi üzerinden yapılan kentsel dönüşüm uygulamalarında yerel mülk sahiplerinin anlaşma imkânları daraltılarak, uygulamalardaki şeffaflık da ortadan kaldırılmıştır. Ortaya çıkan sonuç ürününde hak sahiplerinin gerçek payı bilinememektedir. Yüksek rant amaciyla, yerel mülk sahiplerine bir miktar pay verilerek çok yüksek katlı, yoğun ve kırılgan kentlerin oluşmasına yol açan uygulamaların olduğu görülmektedir. Toplam rantın ne kadar olacağı ve bunun kaçta kaçının yerel mülk sahiplerinin hizmetine sunulacağ tümüyle belirsizdir. Bu tür projelerde elbette ki kentsel rant kaçınılmazdır. Ancak oluşabilecek kentsel rant modellenebilir ve denetlenebilir olmall; bunun yerel mülk sahiplerine ve tüm kente dağıtımı da düzenlenebilmelidir.

Ülkemizdeki kentsel dönüşüm uygulamalarında kat ve konut say1sındaki artışlar, kentsel rantı desteklemekte; bu durum kentlerin daha yoğun, sıkışık, sürdürülemez ve kırılgan alanlar haline gelmesine neden olmaktadır. Kentlerin daha sürdürülebilir ve dayanıklı hale gelebilmesi için özel taşınmaz mülkiyeti ile rant arzusunun ehlileştirilmesi ve kentler üzerindeki baskısının azaltılmasının gerekliliği açıktır. Diğer bir deyişle; kentsel dönüşüm uygulamaları, kente özgü belirlenecek olan optimal kent yoğunluğu göz önünde bulundurularak planlanmalıdır. Kentsel yoğunluğun aşırı artışı, sağlık ve ulaşım gibi hizmetlerin yetersiz kalmasına neden olabileceğinden COVID-19 salgını gibi beklenmedik krizler karşısında kentlerin cevap verebilme kapasitesini düşürebilmektedir. Kentsel yoğunluğun kentsel dönüşüm uygulamaları ile optimal hale getirilmesi, kamusal alanların da etkin şekilde planlanmasına olanak sağlayabilir. Optimal yoğunluk ve kamusal alanların birlikte planlanması, özellikle altyapı, sağlık ve ulaşım hizmet kapasitelerinin geliştirilmesine ve kentlerin yeni hizmet modellerine uyum sağlama becerilerine katkı sağlayabilir.

\section{Sonuçlar ve Öneriler}


Günümüzde etkilerini yoğun şekilde yaşadığımız COVID-19 pandemisiyle birlikte, ülkemizde ve tüm dünya kentlerinde sürdürülebilir ve dayanıklı kentsel alanlar oluşturmak adına, kentsel dönüşüm uygulamalarının önemli işlevler üstlenmesi gerektiği ortadadır. Ancak ülkemizdeki kentsel dönüşüm projelerinin gerek mevzuat gerekse uygulama aç1sından tartışılan ve eleştirilen birçok yönü bulunmaktadır. Kentsel dönüşüm projelerinin, sürdürülebilirlik ve dayanıklılık adına belli amaçları gerçekleştirebilmesi için bazı ölçütlerin tanımlanması, bazı sınırlamaların getirilmesi ve bazı hakların net olarak korunması gereklidir. Tüm bu sınırlama, hak ve ölçütler yasal mevzuat ile desteklenmeli; projelerin uygulama aşamalarında da bu yasal mevzuata uyulmalıdır. Önerilecek bu ölçüt, sınırlama ve haklar aşağıdaki şekliyle vurgulanabilir:

- Kentsel dönüşüm projeleri hayata geçirilirken; kentin genel yap1sina ve mevcut imar planlarına uygunluk mutlaka göz önünde bulundurulmalıdir.

- Her kent için kentsel sürdürülebilirlik ve dayanıklılık ölçütleri tanımlanmış olmalıdır. Kentlerin dokusu, işlevi, yapı ve nüfus yoğunluğu, geleceğe yönelik hedefleri vb. birbirinden farklı olduğundan sürdürülebilirlik ve dayanıklılık hedefleri de farklılıklar gösterecektir. Bu nedenle belirlenecek hedef ve ölçütler her kent için aynı ve tek tip değil, kente özgü şekilde tanımlanmalı ve uyulması yasalar ile zorunlu hale getirilmelidir. Çöküntü haline gelen kentsel alanlardaki dönüşüm uygulamaları, tanımlanmış olan bu kentsel sürdürülebilirlik ve dayanıklılık ölçütlerini sağlayacak şekilde planlanmalıdır.

- Ülkemizde çoğunlukla depreme dayanıklı yapı üretme odaklı kentsel dönüşüm projeleri beraberinde kentlerde hızla artan bir rant beklentisinin de önünü açmaktadır. Ancak, rant beklentisi az olan kentsel alanlarda dönüşüm ve yenileme çalışmaları geri plana itilebilmektedir. $\mathrm{Bu}$ durum deprem riski altındaki yapıların varlığını sürdürmesine ve kentsel kırılganlığın devam etmesine sebep olmaktadır.

- Dünyada ve ülkemizde yaşanan COVID-19 salgını ve salgının nüfus yoğunluğu ile ilişkisi göz önünde bulundurulduğunda kentsel dönüşüm projelerinde mutlaka optimal bir nüfus ve yapı yoğunluk kriteri/sınırı getirilmelidir. Bu kriterlerin hangi kentler için ne kadar olması gerektiğine pek çok disiplinden uzman, sivil toplum kuruluşu ve yerel yönetim birlikte karar vermelidir. Kentin ekonomik, sosyal, demografik ve topografik yapısı da optimal kent yoğunluğunun belirlenmesinde dikkate alınmalıdır. Kentsel dönüşüm uygulamalarının belirlenen opti- 
mal kent yoğunluğu dikkate alınarak planlanması kentlerin salgınlar gibi beklenmedik tehditler karşısında kırılganlığını azaltacağı gibi bu tür tehditlere cevap verebilme kapasitesini de arttıracaktır.

- Yine COVID-19 salgını ile birlikte akıllı kent modelleri, yeni ulaşım ve altyapı ağları vb. birçok kentleşme stratejisi de günümüzde yoğun şekilde tartışılır hale gelmiştir. Kentsel dönüşüm uygulama alanlarının planlanmasında özellikle ulaşım, altyapı, yeşil alan, eğitim ve sağlık alanları gibi kamusal alanların, salgınlar da dikkate alınarak yeniden gözden geçirilmesi gerekmektedir. Yeni kentleşme stratejilerinin geliştirilmesi için daha fazla kamusal alana ihtiyaç duyulacaktır. Dönüşüm alanlarında kentsel yoğunlukla birlikte konut alanlarının azaltılması, kamusal alanların arttırılarak temel altyapı hizmetlerinin daha dayanıklı tasarlanmasına olanak sağlayacaktır. Sonuç olarak, salgınlar karşısında da dayanıklı kalabilecek kentlerin yeniden düzenlenmesinde kamusal alanlar, yeni fonksiyon ve yeterlilikler ile tekrar tanımlanabilecektir.

- Kentsel dönüşüm ve yenileme çalışmaları artık, hem bir mülkiyet dönüşüm projesi hem de kentsel rantın yeniden üretildiği ve paylaşıldığı bir alan haline gelmiştir. Bu nedenle, çöküntü haline gelmiş ya da işlevini yitirmiş kentsel alanlarda gerçekleştirilen dönüşüm projelerinde, sürdürülebilir ve dayanıklı kentler oluşturabilmenin başarıya ulaşmasındaki en büyük engel, özel taşınmaz mülkiyeti ve kentsel ranttır. Yeni kent modellerinin planlanmasında oluşabilecek yapı ve nüfus yoğunluğunu kontrol altına almak adına getirilecek kısttlamalar ile özel mülkiyet ve rant arzusu çelişmektedir. Bu çelişkinin önüne geçilmeli, toplum yararı gözetilerek mülkiyet dönüşümü ve adaletli rant paylaşımı sağlanmalıdır. Bu nedenle, mülkiyet ve rant; planlama aşamasında tanımlanacak optimal yapı ve nüfus yoğunluğuna ait amaç fonksiyonları ile sınırlandırılmalıdır.

- Sürdürülebilir ve dayanıklı yeni kent modelleri için maliklerin özel taşınmaz mülkiyeti maddi bir kayba uğratılmaksızın sınırlandırılırken, diğer yandan mülk sahiplerinin, uygulama sonrasında en az bir konuta sahip olabilmeleri gibi barınma hakkını zedelemeyecek çeşitli kıstaslar da esas alınmalıdır. Kentsel dönüşüm uygulamaları özel mülk sahiplerinin barınma hakkını garanti altına almalı; ancak özel mülkiyete bazı s1nırlamalar getirirken, adalet duygusunu da zedelememelidir. Ayrica, kentsel dönüşüm uygulamalarındaki özel mülkiyet için bir üst sınır tanımlanmalı; bu üst sınır, yeni planlamanın amaç fonksiyonları olan kamusal alan alt sınırını ve kentsel yoğunluk üst sınırını tehdit etmeyecek şekilde modellenmelidir. 
- Kentsel dönüşüm uygulamaları, mülk sahipleri ve müteahhitler açısından yeni bir rant kapısı olmaktan çıkarılmalıdır. Müteahhitlerin yeni projelerden elde edecekleri paylar mutlaka yasayla sinırlandırılmalıdır. Oluşacak kentsel rant; müteahhit, mülk sahipleri ve kente ilişkin diğer paydaşlar arasında sürdürülebilir ve dayanıklı kentsel alanlar yaratmak adına adaletli şekilde paylaştırılmalıdır. Adaletli rant paylaşımı mutlaka yasal güvence altına alınmış olmalıdır. 


\section{Extended Abstract}

\section{An Overview of Private Property and Rent in Urban Regeneration Projects in Terms of Urban Sustainability and Resilience}

\author{
Burcu Aslan Okat \\ ORCID: 0000-0001-5796-5127
}

\author{
Cankut Dağdal İnce \\ ORCID: 0000-0001-5954-2478
}

Since the second half of the 20th century, increasing urban sprawl and urban density, and uncontrolled energy consumption have caused a significant increase in environmental problems especially in cities. Therefore, momentous decisions regarding the need for more sustainable planning of cities were taken in the United Nations Human Framework Conference held in Stockholm in 1972 and in the UN Environment and Development Conference, known as the Rio Conference in 1992, with the Agenda21. Serious difficulties and problems are encountered such as managing rapid urbanization, supporting increasing populations, ensuring competence in housing and infrastructure policies, reducing the environmental effects of urban spillage and vulnerability to disasters, and the necessity of developing policies that can solve these problems is discussed in many cities around the world.

Throughout history, natural disasters and crises such as earthquakes, floods, volcano eruptions, and epidemics affected directly the life and economy in the city with serious damage. In the 20th and 21st centuries, planning cities more resistant to natural disasters and crises were also added to the sustainability discussions with the advances in technology.

A sustainable and resilient urban planning is easier and simpler in areas that have just started urbanization than in existing collapsed areas of cities. However, it is argued that zoning plans and applications may be insufficient in reconsidering urban areas that have collapsed in economic, physical, and social terms. There may be problems such as vulnerable 
structures to disasters, insufficient public spaces, complex property statuses and demographic problems in these kind of urban areas. In addition, because of the urban rent expectations can be high in these areas, urban solutions may get difficult. For this reason, urban regeneration projects are used as an important tool in the reconstruction of cities and in solving various urban problems, as well as regional and city plans.

Urban regeneration projects have become a current issue in Turkey after the 1999 Marmara earthquake. These regeneration projects have been mostly earthquake-oriented and urban regeneration-related laws primarily aim to produce earthquake-resistant mass housing. In recent years, Law No. 6306 has accelerated urban regeneration projects in disaster risk areas or structures. However, it is obvious that cities are at risk in many issues such as not only earthquakes but also epidemics nowadays, and earthquake-oriented regenerations will not be sufficient. Throughout history, epidemics have affected the history of urbanization as much as natural disasters or wars. In the 20th century, there were plenty of epidemics such as Spanish flu, Asian flu, AIDS, and Ebola. Even in the first 20 years of the 21st century, numerous new epidemics such as H5N1 bird flu, Asian flu, SARS, MERS, Zika were encountered; and today the dramatic effects of the Covid-19 pandemic are still felt intensely in Turkey and all over the world. Various discussions and studies about the preventions to be taken in this process, urbanization, infrastructure, and transportation models continue. When the distribution of the Covid-19 cases in Turkey and the world cities are examined, it can be seen that the disease spreads rapidly in locations where urban density is high and access to basic services is low. Although there are studies indicating that urban density is not directly related to the number of cases or deaths, it would not be incorrect to declare that urbanization policies are at the center of the problems caused by the inadequacy of public spaces as a result of population density. According to this, it is clear that urban areas should be reorganized to be prepared for new diseases and disasters. The reorganization of public spaces in a way that makes transportation, infrastructure, education, and health services must be much more effective and must reduce the urban density, as well as prevents urban sprawl; somehow a balance must be struck between them. At this point, the concept of optimal city size and optimal density comes into prominence. Although there are different definitions and studies on determin- 
ing the optimal city size or density, the issue of what these criteria will be is still not clearly defined when the literature is examined.

Various urban models are discussed and implemented in order to create sustainable and resilient cities in the world. Although these models are also used in Turkey, their practices are quite limited and few in number. Since urban regeneration projects are one of the most important tools in all kinds of decisions regarding urbanization today, these projects are expected to contribute to urban sustainability and urban resilience. However, urban regeneration projects in Turkey, limiting the people's property rights, removal of living space, forced to live in high-rise buildings, and sharing the resulting rent in an unfair way have led to discussions on many issues.

Urban regeneration activities and legal regulations in the collapsed areas of cities provide a solution opportunity for the complete regulation of old zoning plans and unplanned urbanization. However, urban policies and practices; while it should target healthy urbanization, social benefit, fundamental rights, and freedoms; it is faced with many intertwined constraints and obstacles such as private property insight and rent expectation. Due to this intricate and mutually influencing nature of issues such as property and rent, the necessary action steps for cities to be healthier, planned, and sustainable are getting heavier and more difficult.

This article is written to discuss the negative effects of private property and urban rent in urban regeneration projects in areas that became collapsed, on this regeneration and indirectly on urban sustainability and resilience. For this purpose, the Law No. 6306 and the 73rd Article of the Municipality Law are examined and tried to explained in terms of the status of private property and rent, new regulating needs are discussed, in this study. In the discussion, information on three urban regeneration projects in Kocaeli, two of which have been completed and one at the planning stage, are used as an example. A database is created on the Geographical Information System by associating the parcel, owner, and share information of these applications with each other. In the light of the analysis and findings made for property and density over GIS, it is discussed how private property and urban rent can be handled in urban regeneration, what the constraints can be and how they can be included in legal regulations.

\section{Kaynakça/References}


Akkar, Z. M. (2006). Kentsel dönüşüm üzerine Batıdaki kavramlar, tanımlar, süreçler ve Türkiye. TMMOB Şehir Plancıları Odası Planlama Dergisi, 2(36), 2938. http://www.spo.org.tr/resimler/ekler/edebb6e872f539b_ek.pdf\#page=29 adresinden erişildi.

Akyıldız, A. ve Girgin, K. (2017). İstanbul'un kentsel dönüşümü için üretilen binaların deprem güvenliklerinin araştırılması. Journal of Science and Engineering.

Aldegheishem, A. (2019). Success factors of smart cities: A Systematic review of literature from 2000-2018. Tema. Journal of Land Use, Mobility and Environment, 12(1), 53-64.

Anayasa Mahkemesi. (2019). Türkiye Cumhuriyeti Anayasası (Gerekçeli). (Y. E. Yılmazoğlu ve İ. E. Perdecioğlu, Ed.) (2. Basım.). Ankara: Anayasa Mahkemesi Yayınları. www.anayasa.gov.tr adresinden erişildi.

Arıcan, T., Dündar, Z. B. ve Güven, E. (2018). Denizevler Kentsel Dönüşüm Projesi Coğrafi Bilgi Sistemi. Kocaeli Üniversitesi, Kocaeli.

Arnott, R. (1979). Optimal city size in a spatial economy. Journal of Urban Economics, 6(1), 65-89. doi:10.1016/0094-1190(79)90017-2

Aslan, B. (2017). Kentsel dönüşümde mülkiyet ilişkilerinin regresyon analizleri ile izlenmesi: Erenler Cedit örneği. Kocaeli Üniversitesi Fen Bilimleri Enstitüsü, Kocaeli.

Ayman Güler, B. (1992). Yerel yönetimler. Ankara: TODAİE Yayını.

Bakanlar Kurulu. (2011, 23 Ekim). Bakanlar Kurulu Kararı - Karar Sayısı: 2011/2316 . Resmi Gazete. 11 Şubat 2021 tarihinde https://www.resmigazete.gov.tr/eskiler/2011/10/20111023-18.htm adresinden erişildi.

Bakanlar Kurulu. (2015a, 1 Haziran). Bakanlar Kurulu Kararı - Karar Sayısı: 2015/7608. Resmi Gazete. 11 Şubat 2021 tarihinde https://www.resmigazete.gov.tr/eskiler/2015/06/20150601-10.htm adresinden erişildi.

Bakanlar Kurulu. (2015b, 10 Temmuz). Bakanlar Kurulu Kararı - Karar Sayıs1: 2015/7858. Resmi Gazete. 11 Şubat 2021 tarihinde https://www.resmigazete.gov.tr/eskiler/2015/07/20150710-29.htm adresinden erişildi.

Başkaya, C. (2019). Cedit Mahallesi'nin kentsel dönüşüm öncesi Coğrafi Bilgi Sistemi ile mevcut durumunun analizi. Kocaeli Üniversitesi, Kocaeli.

Batty, M. (2020). The Coronavirus crisis: What will the post-pandemic city look like? Environment and Planning B: Urban Analytics and City Science. doi:10.1177/2399808320926912

Birleşmiş Milletler. (2018). Sürdürülebilir kalkınma amaçları | UNDP Türkiye. 2 Ocak 2021 tarihinde https://www.tr.undp.org/content/turkey/tr/home/sustainabledevelopment-goals.html adresinden erişildi. 
Boratav, K. (2004). Tarımsal Yapılar ve Kapitalizm (3.). Ankara: İmge Kitabevi Yayınları.

Boterman, W. R. (2020). Urban-Rural polarisation in times of the Corona outbreak? The early demographic and geographic patterns of the SARSCoV-2 Epidemic in the Netherlands. Tijdschrift voor economische en sociale geografie, 111(3), 513-529. doi:10.1111/tesg.12437

Çahantimur, A. ve Turgut Yıldız, H. (2008). Sürdürülebilir kentsel gelişmeye sosyokültürel bir yaklaşım: Bursa örneği. İTÜDERGÍSİ/a, 7(2). http://www.itudergi.itu.edu.tr/index.php/itudergisi_a/article/view/166 adresinden erişildi.

Carozzi, F., Provenzano, S. ve Roth, S. (2020). Urban density and COVID-19. IZA Institute of Labor Economics, (13440), 1-27. www.iza.org adresinden erişildi.

Çelik, K. (2007). Tarım topraklarının kentsel arsa olarak imara açılmasının getirmiş olduğu sorunlar. TMMOB Harita ve Kadastro Mühendisleri Odası 11. Türkiye Harita Bilimsel ve Teknik Kurultayı, 2-6 Nisan 2007 içinde . Ankara.

Çelikbilek, A. ve Öztürk, Ç. (2017). 6306 Sayılı Kanun kapsamında yürütülen kentsel dönüşüm çalışmaları ve İzmir uygulamaları. Medeniyet Sanat, IMÜ Sanat, Tasarım ve Mimarlık Fakültesi Dergisi, 3(2), 187-213.

Çevre ve Şehircilik Bakanlığı. (2012, 15 Aralık). Afet Riski Altındaki Alanların Dönüştürülmesi Hakkında Kanunun Uygulama Yönetmeliği. Resmi Gazete. $11 \quad$ Şubat $2021 \quad$ tarihinde https://www.resmigazete.gov.tr/eskiler/2012/12/20121215-1.htm adresinden erişildi.

Chen, C., Xu, L., Zhao, D., Xu, T. ve Lei, P. (2020). A new model for describing the urban resilience considering adaptability, resistance and recovery. Safety Science, 128. doi:10.1016/j.ssci.2020.104756

Cotella, G. ve Brovarone. (2020). Questioning urbanisation models in the face of COVID-19. Tema. Journal of Land Use, Mobility and Environment, 105-118. doi:10.6092/1970-9870/6869

Cusack, P. T. E. (2017). Physical economics and optimum population density. Journal of Global Economics, 05(01), 1-6. doi:10.4172/2375-4389.1000244

Demirkol, S. ve Bereket Baş, Z. (2013). Kentsel dönüşümün, 6306 Sayılı Yasa kapsamında hak ve özgürlükler açısından ele alınması. TBB Dergisi, (108), 23-70. http://tbbdergisi.barobirlik.org.tr/m2013-108-1305 adresinden erişildi.

Desai, D. (2020). Urban densities and the Covid-19 pandemic: Upending the sustainability myth of global megacities. Observer Research Foundation, 244(May), 1-38.

Donnison, D. (1993). The challenge of urban regeneration for community development. Community Development Journal, 28(4), 293-298. doi:10.1093/cdj/28.4.293 
Ersoy, M. (1997). İmar plan değişiklikleri ve yargı denetimi. ODTÜ Mimarlık Fakültesi Dergisi, 17(1-2), 53-73.

Gargiulo, C., Gaglione, F., Guida, C., Papa, R., Zucaro, F. ve Carpentieri, G. (2020). The role of the urban settlement system in the spread of Covid-19 pandemic. The Italian case. Tema. Journal of Land Use, Mobility and Environment, (Special Issue Covid-19 vs City-20 Scenarios, insights, reasoning and research), 189-212. doi:http://dx.doi.org/10.6092/19709870/6864

Granger, R. (2010). What now for urban regeneration? Proceedings of the Institution of Civil Engineers Urban Design and Planning 163, (1), 9-16. doi:10.1680/udap.2010.163.1.9

Güzey, Ö. (2016). The last round in restructuring the city: Urban regeneration becomes a state policy of disaster prevention in Turkey. Cities, 50, 40-53. doi:10.1016/j.cities.2015.08.010

Hamidi, S., Sabouri, S. ve Ewing, R. (2020). Does density aggravate the COVID19 pandemic?: Early findings and lessons for planners. Journal of the American Planning Association, 86(4), 495-509. doi:10.1080/01944363.2020.1777891

Haştemoğlu, H. ve Özgen, L. (2017). 1960'larda sürdürülebilirlik ve kentleşme; Isparta İstasyon Caddesi örneği. Süleyman Demirel Üniversitesi Mimarlık Bilimleri ve Uygulamalarn Dergisi, 2(1), 69-76.

Haştemoğlu, H. Ş. (2006). 1960'larda sürdürülebilirlik ve kentleşme; Isparta İstasyon Caddesi örneği. Süleyman Demirel Üniversitesi Fen Bilimleri Enstitüsü, Isparta.

Honey-Rosés, J., Anguelovski, I., Bohigas, J., Chireh, V., Daher, C., Konijnendijk, C., ... Nieuwenhuijsen, M. (2020). The impact of COVID-19 on public space: A Review of the Emerging Questions. Cities \& Health, (April), 1-17. doi:10.1080/23748834.2020.1780074

İhlas Haber Ajansı. (2020, 21 Mayıs). İzmit Cedit'teki kentsel dönüşümü Bakanlık ve Büyükşehir yapacak. Haberler.com. 11 Şubat 2021 tarihinde https://www.haberler.com/izmit-cedit-teki-kentsel-donusumu-bakanlikve-13246973-haberi/ adresinden erişildi.

Ince, C. D. ve Aslan, B. (2019). Monitoring the effects of land sizes on private property transformation in an urban regeneration project by regression analysis: Erenler Cedit case study, Kocaeli. Sustainable Cities and Society, 50. doi:10.1016/j.scs.2019.101632

İşte Kocaeli Gazetesi. (2020, 21 Mayıs). Cedit'teki Kentsel Dönüşüm İçin Yeni Protokol. İşte Kocaeli Gazetesi. 11 Şubat 2021 tarihinde https://www.istekocaeli.com/haber/4580405/ceditteki-kentsel-donusumicin-yeni-protokol adresinden erişildi.

Jones, P. ve Evans, J. (2008). Urban regeneration in the UK: Theory and practice. London. 
Karasu Asnaz, M. (2019). Sürdürülebilir ve çok yönlü akıllı kent kavramının temel taşları. Nevşehir Bilim ve Teknoloji Dergisi. doi:10.17100/nevbiltek.568261

Kasapoğlu, Ç. (2020, 26 Mart). Koronavirüs: Salgın hastalıklar tarihi uzmanı Prof. Snowden'a göre "daha insani ve dirençli” bir toplum yaratabiliriz. BBC News Türkçe. 11 Şubat 2021 tarihinde https:/www.bbc.com/turkce/haberler-dunya-52046490 adresinden erişildi.

Kaya, H. E. ve Taylan Susan, A. (2020). Sürdürülebilir bir kentleşme yaklaşımı olarak, ekolojik planlama ve eko-kentler. IDEALKENT-Kent Araştırmaları Dergisi, 11(30), 909-937. doi:10.31198/idealkent.533730

Kocaeli Büyükşehir Belediyesi. (2019, 20 Şubat). İlçelerin ortalama hanehalkı büyüklüğü. Sayılarla Kocaeli. 11 Şubat 2021 tarihinde https:/www.kocaeli.bel.tr/tr/main/pages/ilcelerin-ortalama-hanehalkibuyuklugu/885 adresinden erişildi.

Kocaeli Ses Gazetesi. (2020, 27 May1s). 235 kişi virüsten ölmüş. Kocaeli Ses Gazetesi. $\quad 11 \quad$ Şubat $2021 \quad$ tarihinde https://www.seskocaeli.com/haber/4725826/235-kisi-virusten-olmus adresinden erişildi.

Korkmaz, C. ve Balaban, O. (2020). Sustainability of urban regeneration in Turkey: Assessing the performance of the North Ankara Urban Regeneration Project. Habitat International, 95(October 2019), 102081. doi:10.1016/j.habitatint.2019.102081

Lohrey, S. ve Creutzig, F. (2016). A 'sustainability window' of urban form. Transportation Research Part D: Transport and Environment, 45, 96-111. doi:10.1016/j.trd.2015.09.004

Mattoni, B., Pompei, L., Losilla, J. C. ve Bisegna, F. (2020). Planning smart cities: Comparison of two quantitative multicriteria methods applied to real case studies. Sustainable Cities and Society, 60, 102249. doi:10.1016/j.scs.2020.102249

Meerow, S., Newell, J. P. ve Stults, M. (2016). Defining urban resilience: A review. Landscape and Urban Planning. doi:10.1016/j.landurbplan.2015.11.011

Mutlu Laboç, Ö. (2020). Türkiye'de kentsel dönüşüm, riskli yapılar ve mülkiyet hakkına etkisi. Hacettepe Üniversitesi, Ankara.

Nesticò, A. ve Sica, F. (2017). The sustainability of urban renewal projects: a model for economic multi-criteria analysis. Journal of Property Investment and Finance, 35(4), 397-409. doi:10.1108/JPIF-01-2017-0003

Ökmen, M. ve Bayar, C. (2016). Kentsel dönüşüm ve insan hakları.

Ökmen, M. ve Yurtsever, H. (2010). Kentsel planlama sürecinde oluşan kamusal rantın vergilendirilmesi. Maliye Dergisi, (158), 58-74.

Önal, N. E. (2010). Cumhuriyet tarihi boyunca toprak mülkiyetinin dönüşümü. 
Toplum ve Hekim Dergisi, 25(2), 103-115.

Özcan, Ü. (2000). İmar mevzuatının ve kentsel toprak mülkiyetinin irdelenmesi. Ankara.

Öztaş Karlı, R. G. ve Çelikyay, S. (2020). Akıllı kentlerin gelişiminde Covid-19 etkisi. Yüzüncü Yıl Üniversitesi Sosyal Bilimler Enstitüsü Dergisi, (Salgın Hastallklar Özel Say1s1), 321-338. https://dergipark.org.tr/en/pub/yyusbed/772092 adresinden erişildi.

Peng, Y., Lai, Y., Li, X. ve Zhang, X. (2015). An alternative model for measuring the sustainability of urban regeneration: The way forward. Journal of Cleaner Production, 109, 76-83. doi:10.1016/j.jclepro.2015.06.143

Pontrandolfi, P. ve Manganelli, B. (2018). Urban regeneration for a sustainable and resilient city: An experimentation in Matera. Lecture Notes in Computer Science (including subseries Lecture Notes in Artificial Intelligence and Lecture Notes in Bioinformatics) içinde (C. 10964 LNCS, ss. 31-43). Springer Verlag. doi:10.1007/978-3-319-95174-4_3

Roberts, P. ve Sykes, H. (2000). Urban regeneration: A handbook. http://libris.kb.se/bib/20693927 adresinden erişildi.

Şahin, Ç. (2015). Türkiye'de kentsel dönüşüme dayalı inşaat odaklı ekonomi modeli ve toplumsal maliyeti: En temel insan hakları, sosyal haklar, çevre hakkı ve kent hakkı açısından eleştirel bir değerlendirme. Sosyoloji Konferanslart, 51(1), 51-81. doi:10.18368/iu/sk.09445

Salama, A. M. (2020). Coronavirus questions that will not go away: interrogating urban and socio-spatial implications of COVID-19 measures [version 1; peer review: 3 approved]. Emerald Open Research, 2(14). doi:10.35241/emeraldopenres.13561.1

Saunders, W. S. A. ve Becker, J. S. (2015). A discussion of resilience and sustainability: Land use planning recovery from the Canterbury earthquake sequence, New Zealand. International Journal of Disaster Risk Reduction, 14, 73-81. doi:10.1016/J.IJDRR.2015.01.013

Sayın, Ö. ve Bozkurt, V. (2020). Pandemide küresel kentte yaşamak: İstanbul'un COVID-19 deneyimi. D. Demirbaş, V. Bozkurt ve Y. Sayım (Ed.), COVID19 Pandemisinin Ekonomik, Toplumsal ve Siyasal Etkileri içinde (1. bs., ss. 204-216). İstanbul: İstanbul Üniversitesi Yayınevi. doi:10.26650/B/SS46.2020.005.13

Selçuk, H. (2013). Mülkïyet hakkı -Kamu yararı- Plan kararları ilişkisinin sorgulanması: İstanbul - Kadıköy - Merdivenköy örneği. Bahçeşehir Üniversitesi Fen Bilimleri Enstitüsü, İstanbul.

Sevindik, S. (2009). İmar planlarıyla oluşan kentsel rantın kamuya kazandırılması için ülkemizde kullanılan araçlar. Mahalli İdareler Dergisi, 175(Mart), 53-64.

Shen, L.-Y., Ochoa, J. J., Shah, M. N. ve Zhang, X. (2011). The application of urban sustainability indicators - A comparison between various practices. 
Habitat International, 35(1), 17-29. doi:10.1016/j.habitatint.2010.03.006

Sılaydın Aydın, M. B. ve Kahraman, E. D. (2019). Kompakt kent ölçütlerinden biri olan yoğunluk tespiti ve değerlendirmesi: Türkiye kentleri (İl merkezleri) örneği. Planlama Dergisi, 29(2), 171-183. doi:10.14744/planlama.2019.86547

Tekeli, İ. (1988). Mülkiyet kurumu, kamu yararı kavramı ve imar planları üzerine. Planlama Dergisi, 2, 6-13. http://www.spo.org.tr/resimler/ekler/9ae49a23f67c759_ek.pdf adresinden erişildi.

TMMOB Şehir Plancıları Odası. (2020, 24 Mart). Halk sağlığı aynı zamanda toplumsal mekan ve kamucu planlama sorunsalıdır. TMMOB Basın Açıklaması. 11 Şubat 2021 tarihinde http://www.tmmob.org.tr/icerik/spohalk-sagligi-ayni-zamanda-toplumsal-mekan-ve-kamucu-planlamasorunsalidir adresinden erişildi.

Tuğaç, Ç. (2020). Kentsel sürdürülebilirlik ve kentsel dirençlilik perspektifinden tarihteki pandemiler ve Covid-19 pandemisi. Van Yüzüncü Yıl Üniversitesi Sosyal Bilimler Enstitüsü Dergisi, (Salgın Hastalıklar Özel Sayısı), 259-292. https://dergipark.org.tr/en/download/article-file/1210578 adresinden erişildi.

Tuğcu, P. ve Vural Arslan, T. (2018). Kentsel dönüşüm konulu tez çalışmalarında (1999-2017) öne çıkan konular, sorunlar ve öneriler. Paradoks Ekonomi Sosyoloji ve Politika Dergisi, 14(1), 87-127. https://dergipark.org.tr/tr/pub/paradoks/issue/41450/467612 adresinden erişildi.

Tümler, S. S. ve Karagüler, M. E. (2020). Türkiye'de kentsel yenileme. Hazır Beton Dergisi, (Ocak-Şubat), 73-76. http://www.thbb.org/media/411766/hazir_beton_dergisi_makale_turkiyed e_kentsel_yenileme_157.pdf adresinden erişildi.

Turan, A. (2008). Türkiye'de kentsel rantın oluşumu ve bölüşümü: Devlet mülkiyetinden özel mülkiyete geçiş süreci. Ankara Üniversitesi, Ankara.

Türkiye Büyük Millet Meclisi. Kat Mülkiyeti Kanunu. Resmi Gazete (1965). Türkiye. https://www.mevzuat.gov.tr/MevzuatMetin/1.5.634.pdf adresinden erişildi.

Türkiye Büyük Millet Meclisi. Belediye Kanununda Değişiklik Yapılmasına İlişkin Kanun. Resmi Gazete (2010). Türkiye. https://www.resmigazete.gov.tr/eskiler/2010/06/20100624-2.htm adresinden erişildi.

Türkiye Büyük Millet Meclisi. Afet Riski Altındaki Alanların Dönüştürülmesi Hakkında Kanun. Resmi Gazete (2012). Türkiye. https://www.resmigazete.gov.tr/eskiler/2012/05/20120531-1.htm adresinden erişildi.

Ulubaş Hamurcu, A. ve Aysan Buldurur, M. (2017). Sürdürülebilir kentsel 
dönüşüm için performans göstergeleri. Planlama Dergisi, 27(3), 222-235. doi:10.14744/planlama.2017.30074

United Nations Human Settlements Programme. (2020). World Cities Report 2020

- The Value of Sustainable Urbanization. Nairobi. doi:10.18356/c41ab67e-en

United Nations Office for Disaster Risk Reduction. (2009). Resilience. 2009 UNISDR Terminology on Disaster Risk Reduction. 11 Şubat 2021 tarihinde https://www.undrr.org/terminology/resilience adresinden erişildi.

Yalçıner Ercoşkun, Ö. (2018). Sürdürülebilir kentsel planlama ve tasarım- Dünya örnekleri. Gazi Kitabevi.

Yaman-Galantini, Z. D. (2021). Kentsel dayanıklılık perspektifinde salgınlarla mücadele. Mimarlık, 58(417), 31-34.

Yaman Galantini, Z. D. (2018). Urban resilience as a policy paradigm for sustainable urban planning and urban development: The case of Istanbul. papers2://publication/uuid/512EBCE8-D635-4348-A67D-22DD52988F4C adresinden erişildi.

Yaman Galantini, Z. D. (2019). Catching on "Urban Resilience" and examining "Urban Resilience Planning". IDEALKENT-Kent Araştırmaları Dergisi, 10(28), 882-906. doi:10.31198/idealkent.621492

Yang, Z. (2020). Development of optimal city size theory: A critical view. Journal of Resources and Ecology, 11(1), 100. doi:10.5814/j.issn.1674-764x.2020.01.010

Yarmohammadian, N., Asgary, A., Akbari, N. ve Movahedinia, N. (2014). Optimal and sustainable city size by estimating surplus function for metropolitans of Iran. International Journal of Business and Development Studies, 6(1), 21-38.

Yıldız, S., Kıvrak, S. ve Gültekin, A. B. (2015). Sürdürülebilir kentsel dönüşüm. 2nd International Sustainable Buildings Symposium, Turkey içinde .

Zheng, H. W., Shen, G. Q. ve Wang, H. (2014). A review of recent studies on sustainable urban renewal. Habitat International, 41, 272-279. doi:10.1016/j.habitatint.2013.08.006 